\title{
Development of Best Management Practices for Controlling the Non-Point Sources of Pollution Around Lake Victoria Using SWAT Model: A Case of Simiyu Catchment Tanzania
}

\author{
R.J. Kimwaga ${ }^{a,}{ }^{*}$, D.A. Mashauri ${ }^{a}$, F. Bukirwa ${ }^{a}$, N. Banadda ${ }^{\text {b }}$ U.G. Walic ${ }^{\text {and I. Nhapi }}{ }^{\text {d }}$ \\ ${ }^{a}$ University of Dar es Salaam, Department of Water Resources Engineering, P. O. Box 35131, Dar es Salaam, Tanzania \\ ${ }^{b}$ Makerere University, Faculty of Agriculture, P.O. Box 7062 Kampala, Uganda \\ ${ }^{c}$ National University of Rwanda, Faculty of Applied Sciences, P.O. Box 117 Butare, Rwanda \\ ${ }^{d}$ Department of Civil Engineering, University of Zimbabwe, Box MP 167, Mt. Pleasant, Harare, Zimbabwe
}

\begin{abstract}
Recent studies carried out in Lake Victoria Basin have identified major sources of Non-Point Source (NPS) of pollution in the Simiyu catchment of Lake Victoria using land-uses of 1975 and 2006 and compared the relative impact of land-use change on sediment and nutrient load (P and N) into the Lake. The main aim of this study was to identify and develop Best Management Practices to control NPS pollution in the Simiyu Catchment. The SWAT model was used to stimulate and assess the Best Management Practices Scenario for the catchment. The catchment was divided into seven (7) sub-basins. The results show that there was no intensive use of artifical fertilisers in the catchment and manure is the major type of fertiliser in use. Simulation was done for the period 2000 to 2005 . High nutrient concentration was observed in Sub-basin 6; 0.558-0.779 kgN/ha/yr than in Sub-basin 7; 0.018-0.115 kgN/ha/yr, despite the larger area of coverage by the latter. This is also irrespective of the fact that Sub-basin 7 covers a larger area, $3,426.52 \mathrm{~km}^{2}$ compared to Sub-basin 6 $\left(72.97 \mathrm{~km}^{2}\right)$ and Sub-basin $4\left(618.16 \mathrm{~km}^{2}\right)$. Relatively, considering their size, Sub-basin 6 produces higher pollution than Sub-basin 7. It was also observed that the sediment yield from the whole catchment reduced from 81,222 ton/yr to 98,400 ton/yr.It was observed that to control the NPS pollution problem, Best Management Practices like reduced manure application rate, tillage and contour yielded a decrease of $1.4 \%$ in $\mathrm{N}$ load and $1.57 \%$ in sediment load. As a result, it was concluded that the SWAT modelling tool can be used in developing Best Management Practices because pollutant processes per sub-catchment had been fully understood. With good model performance, developing management strategies to control NPS pollution around Lake Victoria can be achieved using the SWAT model. The BMPs have been devised depending on the sub-basin, which has a big collective reduction and control in NPS pollution in the whole catchment.
\end{abstract}

Keywords: Best management practice, fertilizer and pesticide application, nps control, nutrients and sediments yield, swat modelling application.

\section{INTRODUCTION}

Lake Victoria in East Africa is the second largest freshwater body in the world with a surface area of $68,500 \mathrm{~km}^{2}$, and a maximum depth of $84 \mathrm{~m}$. The catchment area extends for $184,000 \mathrm{~km}^{2}$ and it has a shoreline length of $3,440 \mathrm{~km}$. The lake is shared by Kenya (6\%), Uganda (43\%) and Tanzania $(51 \%)$. Although these three countries border the lake, streams and rivers stretching as far as Burundi and Rwanda also feed into it. It is also important to note that Lake Victoria is the source of the River Nile whose waters are greatly committed downstream.

In recent years, environmental challenges have beset the lake. It is not only a source of food, water, employment,

*Address correspondence to this author at the University of Dar es Salaam, Department of Water Resources Engineering, P. O. Box 35131, Dar es Salaam, Tanzania; Tel: + 255754265636 or +255718 527255 ;

E-mail: rkimwaga2007@yahoo.com or richard.kimwaga@iwmnet.eu transport, hydroelectric power, and recreation, but now it is also used as a dumping ground for various types of waste [1-3]. LVEMP [4] states that three of the cities of East Africa namely Mwanza, Kampala and Kisumu, and several major towns and urban centres within the basin with a total population of nearly 5 million receive their water supply from the lake. However, according to Kyomuhendo [5], the once clear, life-filled Lake Victoria is now murky and smelly. Furthermore, these days, the pollution impact by municipal and industrial discharges is visible in some of the rivers feeding the lake and along the shoreline, such as the shallow Winam Gulf in Kisumu (Kenya) and near Mwanza (Tanzania) and Kampala City (Uganda). The ecological health of Lake Victoria has been affected profoundly because of a rapidly increasing human population, which caused the migration of plantation workers to the area, clearance of natural vegetation along the shores to establish plantations of coffee, tea and sugar [4]. Kyomuhendo [5] and Larsson [6] identified the profile growth of algae in the lake 
while Matagi [2] writes about dumping untreated effluent by several industries. The National Water and Sewerage Corporation charged with treating and supplying water to Kampala City dwellers have been complaining of rising treatment costs [7].

Pollution in the Lake Victoria is on the rise [8]. Part of the pollutants associated with non-point source (NPS) end up in the lake where they result in the lowering of dissolved oxygen, raising of nutrient concentrations, and increasing turbidity. The consequences of this are algae blooms, fish kills, insurgency of waterweeds (such as water hyacinth), and water-borne diseases. Land-use change over the years is one of the factors positively correlating with the deterioration in lake water quality. According to Campbell et al. [8], pollutant loading in Lake Victoria due to land-based activities has received substantial, though not adequate, attention. Non-point sources of material input into the lake in many occasions have been neglected and in most cases, they are implicated by circumstantial evidences.

The relationship between poor land-use practices and NPS pollution was recently established [9-11]. Identifying and quantifying NPS hotspots and establishing a relationship between land-use change and water quality deterioration will contribute to the development of strategies for catchment management to control impacts related to the same. It is clear that pollution is one of the major problems facing Lake Victoria and one of the major consequences of that pollution is eutrophication, which is as a result of nutrient inflows into the lake. The most important nutrients as far as the eutrophication of Lake Victoria is concerned are nitrogen and phosphorus. Sediments are also a factor as they absorb nutrients and some other pollutants. Nitrogen and phosphorus in the Lake originate from organic and inorganic fertilizers discharged from intensive agricultural activities, sewage from cities, and livestock grazing. As catchment land-use changes towards more agricultural land, bare grounds and residential areas, more pollutants are generated and directed into the lake.

Several studies have identified point source pollution as one of the largest problems causing water quality deterioration in Lake Victoria [9-11]. Though enormous attention had been invested in tackling the pollution problem based on point source pollution, recent studies have reported on quantification of Non Point Source (NPS) of pollution into Lake Victoria [9-11]. Studying the NPS hot spots and their contribution to lake pollution and relating this to land-use change in the catchment is an important move to set measures for the best management of the catchment land-uses and reduction in deterioration of the lake water quality. Despite recent studies [9-11] reporting on the NPS hotspots and their quantification, there is no record of published work from the study area related to development of best management practices (BMP) in a more quantitative way using modelling tools like SWAT. Therefore, there is a need to apply a more quantified BMP using a modelling tool in the study area. The main aim of this study was to identify and develop the Best Management Practices to control NPS pollution in the Simiyu Catchment Using SWAT model. The specific objectives are twofold: (1) To identify the fertilisers and pesticides applied in the Simiyu Catchment and (2) to quantify the nu- trients and sediment yields from fertilisers and pesticides application with the view of coming up with the BMP for the catchment. Best Management Practices can be defined as those best sought practices to reduce the impact of a degrading action. For instance, they can be a combination of several conservation practices like land treatment practices, production practices and technologies. The difference between this paper from the earlier papers is that this paper deals with development of best management practices for controlling non-point source of pollution in Simiyu Catchment.

\section{METHODOLOGY}

\subsection{Description of Study Area}

\subsubsection{Location}

This study was conducted in the Simiyu Catchment, located between $33^{0} 15^{\prime}-35^{\circ} 00^{\prime} \mathrm{E}$ and $2^{0} 3^{\prime}-3^{0} 30^{\prime} \mathrm{S}$ in the South-Eastern part of Lake Victoria (Fig. 1). The Simiyu River drains the Serengeti National Park plains and partly the Mau ranges in Kenya to Lake Victoria on the downstream before it discharges its waters to the Lake [12]. The Simiyu Catchment has an area of about $10,312 \mathrm{~km}^{2}$. It discharges into the Lake at the Speke Gulf and is considered as one of the main sources of nitrogen, phosphorus and sediment load into the Lake [12].

\subsubsection{Climate}

The catchment experiences a bimodal rainfall patternof rainfall with a short raining season from November to December and long one from March to May. The mean annual rainfall ranges from 700 to $1,000 \mathrm{~mm}$. The catchment has a warm tropical savannah climate with an average temperature of about $23^{\circ} \mathrm{C}$ and it is in the semi-arid part of Tanzania. According to Rwetabula et al., [13] sandy loam soil is the major soil type of the catchment covering about $60 \%$ of the total in area.

\subsubsection{Hydrology}

The Simiyu River is a tributary of Lake Victoria, joining the Duma River before the two discharge their waters into the Lake at the Speke Gulf. Other smaller rivers in the same catchment are Bariadi River and Ngasomo River. The Simiyu River is ephemeral, which contain water during and immediately after a storm event and dries up during the rest of the year with the exception of some dead channel storage [14]. During the long rainy season, discharge from the river reaches up to $208 \mathrm{~m}^{3} / \mathrm{s}$ [15] and lows of no discharge at all in the dry season.

\subsection{Development of Best Management Practices Using SWAT}

\subsubsection{SWAT Modelling}

SWAT model is a spatially distributed, physically based hydrological model, which can operate on a daily time step as well as in annual steps for long-term simulations up to 100 years. The model allows for predicting the impacts of land-use practices on water quality, sediment yield, and agricultural chemicals yield in ungauged watersheds. For watershed hydrologic and water quality modelling, the major inputs into the model include weather, soil properties, topogra- 


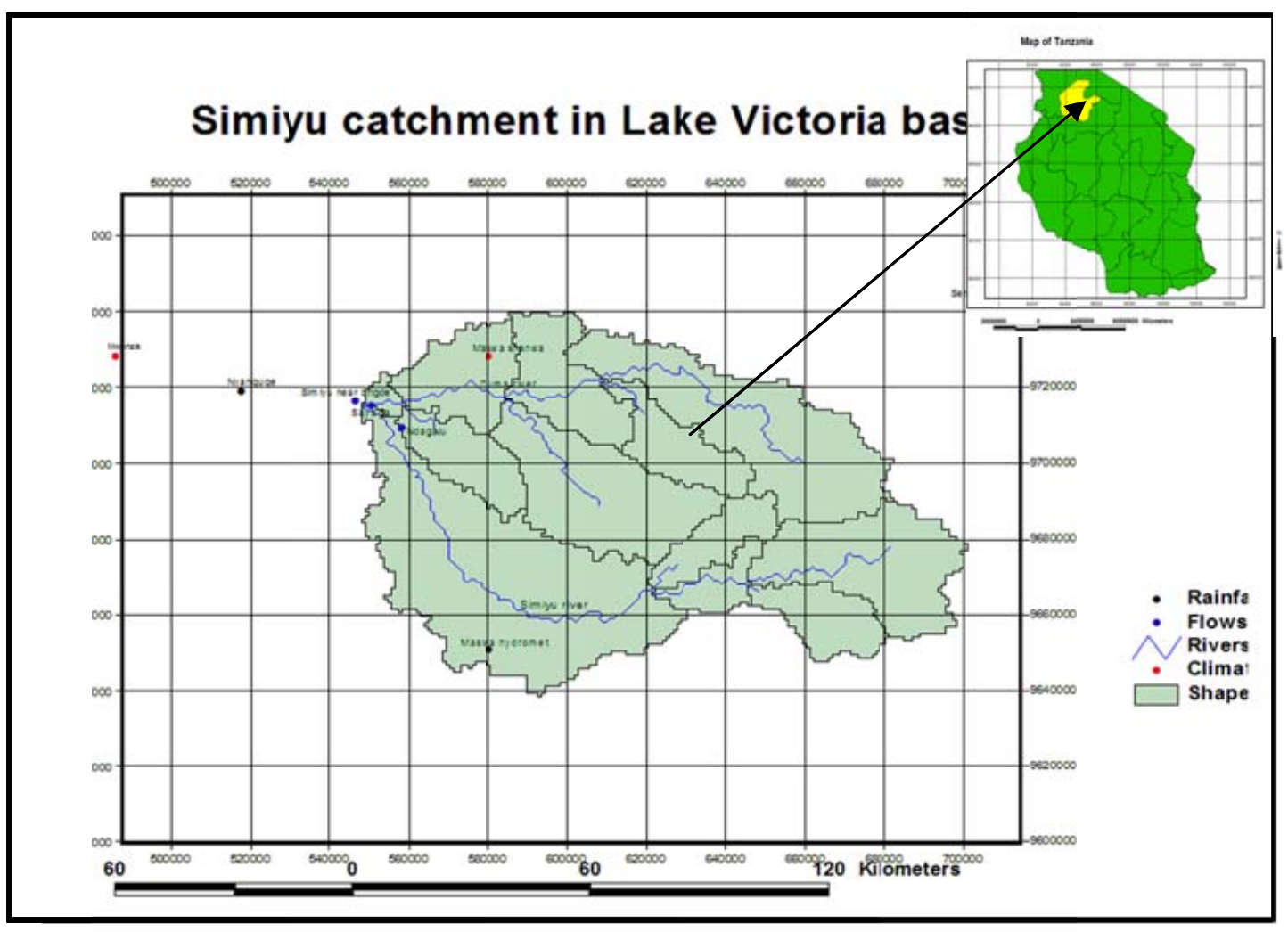

Fig. (1). Location of the Simiyu Catchment in Mwanza region (Tanzania).

phy, vegetation, and land management practices [16]. In operation, the watershed schema is divided into sub-watersheds with unique soil/land-use characteristics called Hydrologic Response Units (HRUs) based on threshold percentages used to select the land-use and soils combination.

\subsubsection{Why Modelling Approach Using SWAT?}

Most research studies have been anchored around field measurements and monitoring pollution of water resources. With non-point source pollution emerging from large watersheds with mixed land-uses and soils, it is quite difficult to associate water pollution to a specific source using monitoring data, unless the process is made very efficient with several sampling points. In this context, the application of a watershed simulation model like SWAT is most useful. Additional advantage of this is that varying conditions of climate, soils, land-use and topography are well considered while applying a spatially distributed model. Details of SWAT Model are described in the other reported studies [9, 10].

\subsubsection{Best Management Practice Scenario Development}

In this research, BMPs were related to nutrient management such as forage harvest management, nutrient management practices, and erosion control like critical area planting, residue management, pasture planting, bush management and contour terracing. These were mainly applied in those sub-basins that were dominated by agriculture. The aim is to come up with feasible management scenarios for pollution control from agriculture and soil erosion.This was focused on only the 2006 land-use and to develop a management scenario, the fertilizer and pesticides options were turned on in the model and a simulation was made to analyze the re- sulting pollutant load for the years between 2000 and 2005 . Tentative management options were loaded after the first simulation to check the relative reduction in the nitrogen and phosphorus amounts coming in from the catchment. The first scenario was without any fertiliser or pesticide application. Pesticide application was loaded for those sub-basins that were under intensive agricultural activity. The pesticides applied were DDT and $\mathrm{HCH}$.

\section{RESULTS AND DISCUSSION}

\subsection{Fertilizer and Pesticide Application}

\subsubsection{Fertilizers}

In order to come up with the best management practice, it was thought that it is important to know the types of fertilizers and pesticide used. It was not possible to visit all farms in the catchment so in this case; secondary data was used backed with discussion with some residents in the area. According to LVEMP [4], since liberalisation in 1995/96, the Regional Agricultural Offices have not been able to get information on the amount of fertilizer and pesticides sold. Therefore, it has not been possible to quantify accurately threats from use of agricultural inputs. In an attempt to determine impact of fertilizers and pesticides, results from a LVEMP field survey done on the quantity and types of agricultural inputs used in the Lake basin area were used. The main types of fertilizers used in the area surveyed are CAN (Calcium, Ammonia, Nitrogen), urea, NPK (Nitrogen, Phosphorous, Potassium), and TSP (Triple Super Phosphate). The nutrient composition of these fertilizers is given in Table $\mathbf{1}$. 
Table 1. Fertilizers Applied in the Simiyu Catchment and their Corresponding Nutrient Concentrations

\begin{tabular}{|l|l|}
\hline Fertilizer & \% of Nutrients $(\boldsymbol{N}, \boldsymbol{P}, \boldsymbol{K})$ \\
\hline CAN & $26 \%$ Nitrogen \\
\hline Urea & $46 \%$ Nitrogen \\
\hline NPK & $20 \%$ Nitrogen, $10 \%$ Phosphates, $10 \%$ Potassium \\
\hline TSP & $46 \%$ Phosphates \\
\hline
\end{tabular}

Due to financial constraints, most farmers in the catchment cannot afford artificial fertilisers and therefore use manure on their farms. The estimated equivalent per tonne of farmyard manure is $5 \mathrm{~kg} \mathrm{~N}, 3 \mathrm{~kg} \mathrm{P}$ and $13 \mathrm{~kg} \mathrm{~K}$, which is equivalent to $3.75 \mathrm{~kg} \mathrm{~N}, 2.25 \mathrm{~kg} \mathrm{P}$ and $9.75 \mathrm{~kg} \mathrm{~K}$ per year per cropped hectare.

\subsubsection{Pesticides}

The majority of pesticides in use in the catchment today are organic compounds. Because organic compounds contain carbon, which is used by microbes in biological reactions to produce energy, organic pesticides may be susceptible to microbial degradation. In contrast, pesticides that are inorganic are not susceptible to microbial degradation. Examples of pesticides that will not degrade are lead arsenate, a metallic salt commonly applied in orchards before DDT was invented, and arsenic acid, a compound formerly used to defoliate cotton.

Rwetabula, et al., [13] discovered that the organochlorine pesticides such as DDT and $\mathrm{HCH}$ were frequently detected in water samples although they were not frequently used in the catchment. As it was not possible to ascertain the exact chemical composition of these brands in terms of percentage volume or weight, the actual amount of chemical pollutants due to these inputs was not determined. However, SWAT has a provision of adding a pesticide name in the extension $(\mathrm{Chm})$ in each sub-basin. So depending on the dominant land-use taking place, this was added to check for the relative increase in nutrient load due to application of the pesticide. It is expected that where the land-use is mainly agriculture, the load of phosphates and nitrate is liable to increase than in any other sub-basin.

\subsection{Nutrient and Sediemnts Yield with Pesticide and Fertiliser Application}

Simulation was done for the period 2000 to 2005. High nutrient concentrationswere seen in Sub-basin 6; 0.558-0.779 $\mathrm{kgN} / \mathrm{ha} / \mathrm{yr}$ than in Sub-basin 7; 0.018-0.115 kgN/ha/yr, despite a larger area of coverage by the latter. The simulation results for NPS are reported in [9, 10]. However for the purposes of refreshing, these are repeated here under.

\subsubsection{Sediments Yield}

The average sediment yield between 1999 and 2000 for the 1975 land-use was $2.8 \times 10^{-5}$ ton/ha.month while that for the 2006 land-use went upto $3.95 \times 10^{-3}$ tons/ha.month i.e. there was a substantial increase in sediment yield in the two periods which definitely resulted into a higher nutrient load in the lake considering surface runoff also increased within the same period. Fig. (2) below shows the sediment yield results.

\subsubsection{Nitrogen Yield}

With application of pesticides and fertilizers set on in the model, there were shooting values for the nitrates load from the 2006 land-use. Average nitrate load went up to 92.2 $\mathrm{kgNO}_{3} / \mathrm{km}^{2} / \mathrm{yr}$ for 2006 from $77.2 \mathrm{~kg} / \mathrm{km}^{2} / \mathrm{yr}$ like shown below. The 1975 land-use had an average of $52.03 \mathrm{kgNO}_{3} / \mathrm{km}^{2} / \mathrm{yr}$. This shows how in 2006 the increased agricultural activity in the catchment with the application of manure and other fertilizers to increase crop production increased nutrient yield in the catchment. Fig. (3) below the results for Nitrate yield.

Analysis of organic nitrogen levels in the catchment with emphasis on Sub-basin 7 showed the average load increased $0.112-0.237 \mathrm{~kg} / \mathrm{ha}$.yr to $1.003-1.339 \mathrm{~kg} / \mathrm{ha} . \mathrm{yr}$ in 1975 and 2006 land-uses respectively.

\subsubsection{Phosphorus Yield}

Mineral phosphorus levels were higher for the 2006 landuse compared to 1975 . This gave an average 54.5286 $\mathrm{kgMin} . \mathrm{P} / \mathrm{km}^{2} / \mathrm{yr}$ and $33.5 \mathrm{kgMin} . \mathrm{P} / \mathrm{km}^{2} / \mathrm{yr}$ respectively. It was observed that due to less consumption of phosphoruscontaining fertilizers in the catchment, the ranges of mineral phosphorus for the two periods were almost close. Organic phosphorus pool is set to $0.03 \%$ of the initial amount of residue on the soil surface while organic $\mathrm{N}$ is $0.15 \%$ of the initial amount of residue on the soil surface. Therefore high levels of organic P and $\mathrm{N}$ in the 2006 land-use can be attributed to large biomass due to agricultural activity than it appears in the 1975 land-use. The Y -axis is Mineral P loads in $\mathrm{kig} / \mathrm{km}^{2} / \mathrm{yr}$. Fig. (4) below shows the mineral yields for 1975 and 2006 scenarios.

From the above results it was observed in all cases that the nutrient and sediment loads reduce in the catchment between July and October because Simiyu River passing through sub-basin7 (which was of major interest in the above analysis) is characterized as an ephemeral river [17]. This implies that the sediment yield and nutrient load into the lake within this time period increased. This can be attributed to the change in vegetation cover that has an impact on surface runoff.

Manure is the main type of fertiliser used in the catchment and application rates were estimated at about $10 \mathrm{~kg} / \mathrm{ha}$. Nutrient concentration used were those mentioned in Table 1. There is non-extensive use of artifical fertilisers (containning phosphorus) in the Simiyu catchment [13]. This was seen by the model presenting the highest phosphorus levels of $0.053-0.887 \mathrm{kgP} / \mathrm{ha} . \mathrm{yr}$ and lowest levels ranging between $0-0.001 \mathrm{~kg} / \mathrm{ha}$.yr. The average sediment yield was 98,469 ton/yrfor the catchment.

These low levels of phosphate yield can also be attributed to the model under-estimation of the sediment load from the Simiyu catchment hence not taking care of the sedimentbound phosphates. Organic $\mathrm{N}$ was calculated based on the amounts in the top soil layer, the sediment yield and an enrichment ratio; which is the ratio of organic $\mathrm{N}$ in sediment to organic $\mathrm{N}$ in the soil. Therefore, since the model performance 


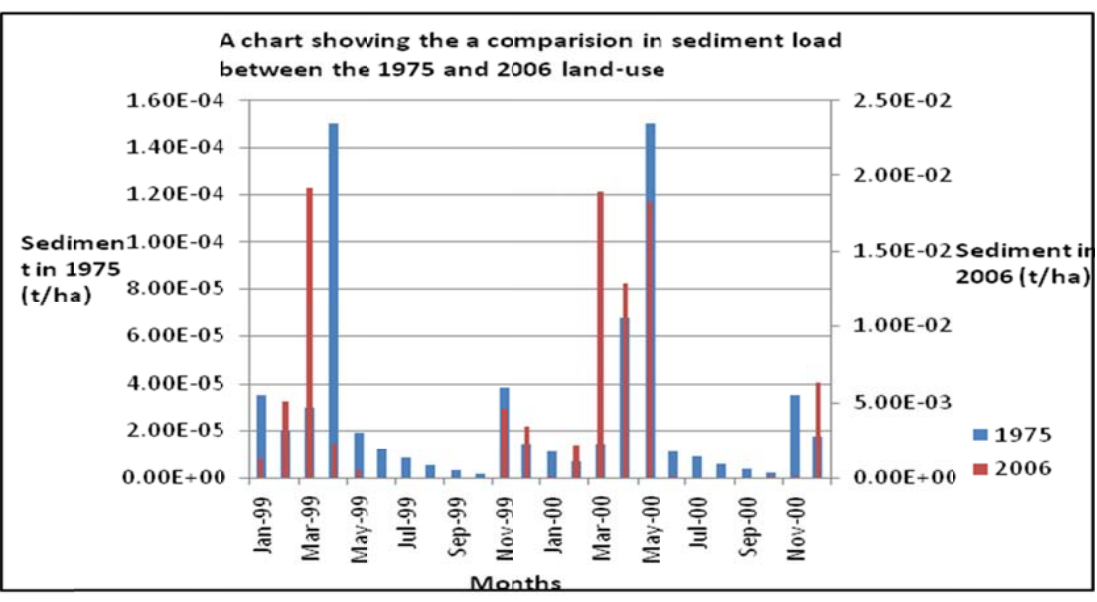

Fig. (2). Comparative analysis of sediment yields based on land uses in the Simiyu Catchment for 1975 and 2006(Source: [9, 10]).

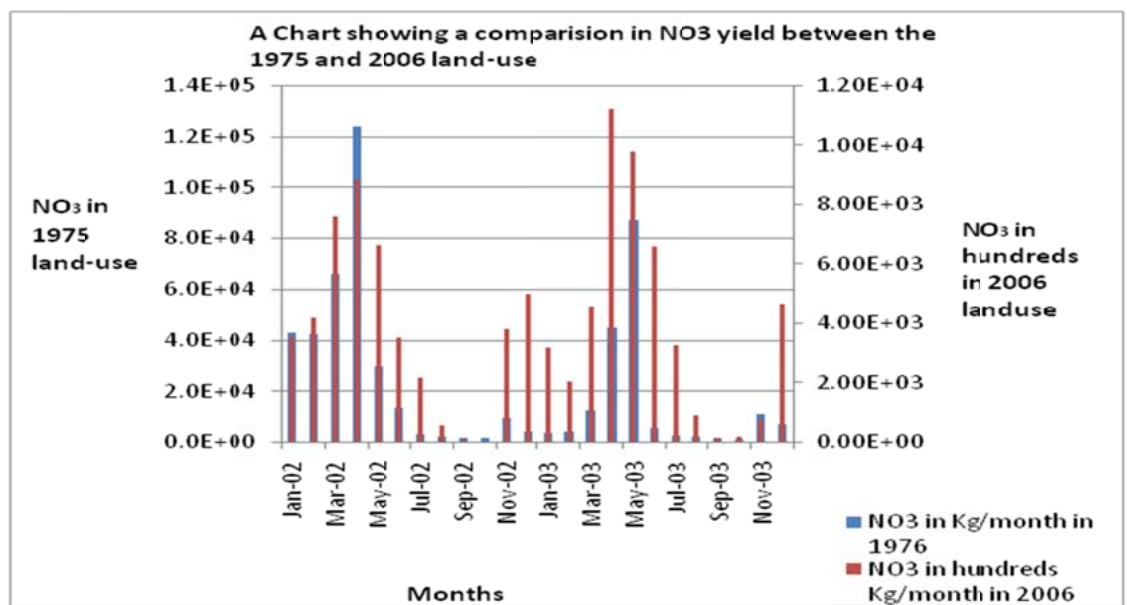

Fig. (3). Comparative analysis of $\mathrm{NO}_{3}$ yields based on land uses in the Simiyu Catchment for 1975 and 2006 (Source: [9]).

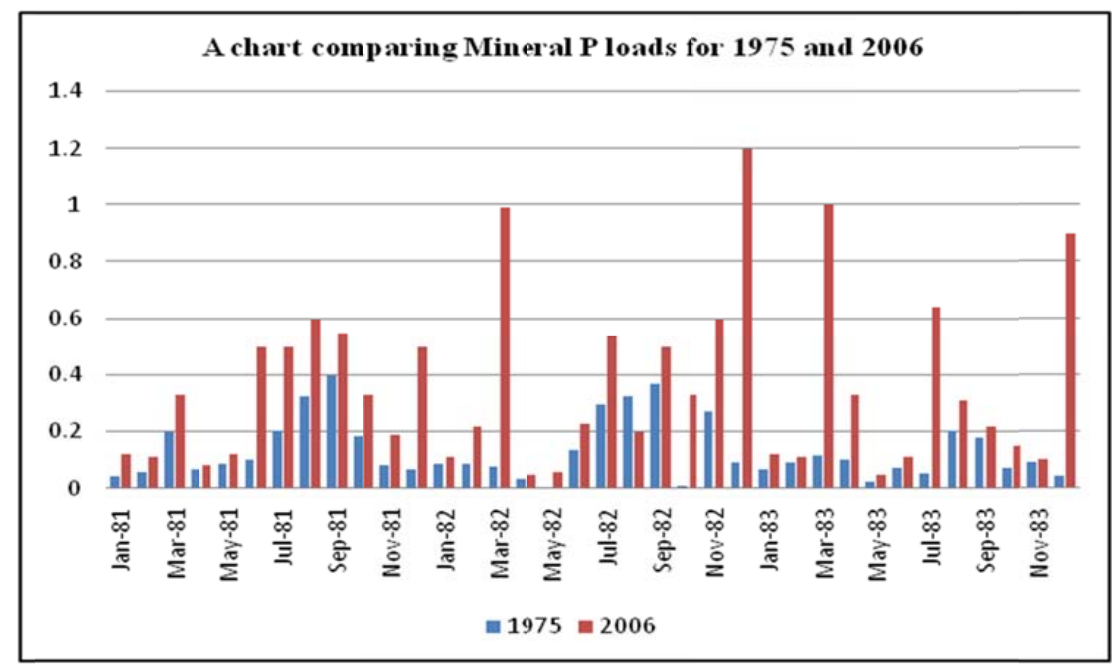

Fig. (4). Comparative analysis of mineral P yields based on land uses in the Simiyu Catchment for 1975 and 2006(Source: [9]).

on sediment simulation was not very reliable, it reduced acceptability of the results from total P load. Conversely, there was no extensive application of phosphorus-containing pesticides or fertilisers in the catchment. Generally, relativley high nutrient yield in surface runoff from the cathcment obtainned by field sampling could also be attributed to the high coverage of sandy loam soils taking up $68.23 \%$ of the catchment. Some pollutants move faster in sandy loam soils than clay loam soil [18].

It can therefore be concluded that more pollution comes into the Lake from the zones along the Simiyu River, with the cotton fields and paddy cultivation in the catchment. 
Table 2. Reduction in the Nitrogen and Sediment Yield in the Simiyu Catchment with Implementation of BMP

\begin{tabular}{|l|c|c|}
\hline Management Option & Reduction in N and Sediment Levels \\
\hline \hline 1. Nitrogen yield changes for manure application reduction from 10ton/ha to 5ton/ha and forage harvest at 50\% & $\begin{array}{c}\text { From } \\
0.066 \mathrm{~kg} / \mathrm{ha} . \mathrm{yr}\end{array}$ & $\begin{array}{c}\text { To } \\
0.052 \mathrm{~kg} / \mathrm{ha} . \mathrm{yr}\end{array}$ \\
\hline 2. Sediment yield reduction from residue management through tillage operations & 98,400 ton/yr & $81,222 \mathrm{ton} / \mathrm{yr}$ \\
\hline
\end{tabular}

Major nutrient yield (especially phosphates) comes in from the extensive cotton fields applying pesticides in the start of the year. These are leached into the water during the long rain season of March to May.

\subsection{Development of Best Management Practices}

After establishing the major polluting zones and understanding how much pollution comes in from these subbasins, inorder to estimate the reductions in NPS due to implementation of BMP, the pre-BMP scenario used was the one explained in the methodology part above. This was done on Sub-basin 7 and 6. Several management practices were then loaded and for each BMP, key processes and parameters influencing the process were identified. These included fertiliser application rates, slope, USLE_C factor (cover and management factor) which were adjusted per run to detect change in nitrate and phosphate yield. Devising possible management strategies or scenarios involved considering other identified sensitive parameters like SOL_ORGN, SLSUBBSN (Average slope length) that appeared during model calibration. These also affected sub-basin nutrient and sediment generation and transport processes and were used to come up with options like tillage and contour ploughing. Manure application rate was first reduced from 10ton/ha to 5 ton/ha, and forage harvest kept at $50 \%$. This resulted into a decrease in nitrogen levels from an average of $0.066 \mathrm{~kg} / \mathrm{ha} . \mathrm{yr}$ in Sub-basin 7 to $0.052 \mathrm{~kg} / \mathrm{ha} / \mathrm{yr}$. There were no much changes on the phosphate or sediment yield. The other option was driven towards the residue left within the catchment. This was done by loading tillage operation. It was observed that the sediment yield from the whole catchment reduced from 98,400 ton/yr to 81,222 ton/yr. Table 2 below shows the reduction in nitrogen and sediment yield with the implementation of BMP in Simiyu.

The reduction in nutrient levels through implementation of BMP were slightly small because the practices were focused on only sub-basin 6 and 7 while those the sediment were spread out through the whole catchment. The first option of reducing the rate of manure application and harvesting the forage while leaving enough plant cover for regrowth reduces area exposed to surface runoff and tillaging will reduce sheet and rill erosion in the catchment. Better results could be achieved if these management options were spread throughout the catchment.

\section{CONCLUSIONS}

The general objective of the study was to develop the Best Management Practise (BMP) for those sub-basins with the highest pollution yield using the land-uses of 1975 and 2006. Specifically it was carried out to identify the fertiliser and pesticide application and quantify the nutrients and sediments yields from fertilizers and pesticides application with the view of developing the BMP using SWAT model. Nutrients and sediments yields from fertilizers and pesticides application were considered as NPS to be controlled. The study has found out that the lower zones of the catchment draining the Simiyu River harbour more NPS of pollution. The Upper zones draining the Duma River are less covered in agriculture. More phosphorus-containing pesticides and artificial fertilisers are used especially in the cotton fields and rice paddies; the impact on water quality is higher from the lower sub-basin in the catchment. Manure is the main type of fertiliser used in the catchment and application rates were estimated between $10 \mathrm{Mg} / \mathrm{ha}$. There is non-extensive use of artifical fertilisers (containning phosphorus) in the Simiyu catchment. This was seen by the model presenting the highest phosphorus levels of $0.053-0.887 \mathrm{kgP} / \mathrm{ha} / \mathrm{yr}$ and lowest levels ranging between $0-0.001 \mathrm{~kg} / \mathrm{ha} / \mathrm{yr}$. Average sediment yield was 98469 ton/yr. The majority of pesticides in use in the catchment today are organic compounds.

It was found out that to control the NPS pollution problem, Best Management Practices proposed in this study are to reduce manure application rate, tillage and contour. Using SWAT model, these BMP yielded a decrease of $1.4 \%$ in N load and $1.57 \%$ in sediment load. It was found out that SWAT modelling tool can be used in developing the Best Management Practices because pollutant processes per subcatchment had been fully understood. With good model performance, developing management strategies to control NPS pollution around Lake Victoria can be achieved using the SWAT model. BMP have been devised depending on the sub-basin, which have a big collective reduction and control in NPS pollution in the whole catchment.

\section{CONFLICT OF INTEREST}

None declared.

\section{ACKNOWLEDGEMENT}

The authors are thankful to the VicRes funding through which this study has been possible.

\section{NOMENCLATURE AND ACRONYMS}

$\%$

${ }^{0} \mathrm{C}$

$\mathrm{kg}$

$\mathrm{kg} / \mathrm{ha} / \mathrm{yr}$

$\mathrm{kgN} / \mathrm{ha} / \mathrm{yr}$

$\mathrm{kgP} / \mathrm{ha} / \mathrm{yr}$

$\mathrm{km}$
$=$ Percentage

$=$ Degree Centigrade

$=$ Kilogram

$=$ Kilogram per hectare per year

$=$ Kilogram of Nitrogen per hectare per year

$=$ Kilogram of Phoporus per hectare per year

$=$ Kilometre 


\begin{tabular}{|c|c|}
\hline $\mathrm{km}^{2}$ & $=$ Square kilometres \\
\hline $\mathrm{m}^{3} / \mathrm{s}$ & $=$ Cubic meters per second \\
\hline $\mathrm{Mg} / \mathrm{ha}$ & $=$ Million gram per hectare \\
\hline $\operatorname{ton} / \mathrm{yr}$ & $=$ Tonnes per year \\
\hline $\mathrm{kgNO}_{3} / \mathrm{km}^{2} / \mathrm{yr}$ & $\begin{array}{l}=\text { Kilogram of nitrate per square } \\
\text { kilometre per year }\end{array}$ \\
\hline $\mathrm{kgMin} . \mathrm{P} / \mathrm{km}^{2} / \mathrm{yr}$ & $\begin{array}{l}=\text { Kilogram Min Phosphorus per square } \\
\text { Kilometre per year }\end{array}$ \\
\hline ton/ha/month & $=$ Tonnes per hectare per month \\
\hline ton/ha & $=$ Tonnes per hectare \\
\hline $\mathrm{mm}$ & $=$ Milimetre \\
\hline $\mathrm{m}$ & $=$ Metre \\
\hline BMP & $=$ Best Management Practise \\
\hline CAN & $=$ Calcium, Ammonia, Nitrogen \\
\hline DDT & $=$ Dichlorodiphenyltrichloroethane \\
\hline $\mathrm{HCH}$ & $=$ Hexachlorocyclohexane \\
\hline HRUs & $=$ Hydrologic Response Units \\
\hline ILIWIS & $\begin{aligned} &= \text { Integrated Land and Water Informa- } \\
& \text { tion System }\end{aligned}$ \\
\hline K & $=$ Potassium \\
\hline LVEMP & $\begin{aligned}= & \text { Lake Victoria Environmental Manage- } \\
& \text { ment Project }\end{aligned}$ \\
\hline $\mathrm{N}$ & $=$ Nitrogen \\
\hline NPK & $=$ Nitrogen, Phosphates, Potassium \\
\hline NPS & $=$ Non-Point Sources \\
\hline $\mathrm{P}$ & $=$ Phosphorus \\
\hline SLSUBBSN & $=$ Slope of Sub Basin \\
\hline SOL_ORGN & $=$ Initial Organic $\mathrm{N}$ concentration \\
\hline SWAT & $=$ Soil and Water Assessment Tool \\
\hline TSP & $=$ Triple Super Phosphate \\
\hline USLE_C & $=$ Universal Soil Loss Equation \\
\hline VICRES & $=$ Victoria Research Project \\
\hline
\end{tabular}

[1] N. Chege, "Lake Victoria: A sick giant". Technical report," World Watch Institute, 1995.

[2] S. V. Matagi, "Some issues of environmental concerns in Kampala, the capital city of Uganda," Environ. Monit. Assess., vol. 77, pp.121-138, 2002.
[3] MWLE, "Land sector strategic plan 2001-2011. Utilizing Uganda's land resources for sustainable development," Report from the Ministry of Water, Land and Environment, Kampala, Uganda, 2006.

[4] LVEMP, "An inventory of agro-chemicals in Lake Victoria basin," Tech. Report. Mwanza, Tanzania, 2000.

[5] P. Kyomuhendo, "A bieconomic model for Uganda's Lake Victoria Nile Perch fishery," Master's thesis, International Fisheries Management, Universitete Tromso, Norway, pp. 24, 2003.

[6] P. Larsson, "Lake Victoria and Kampala-history of man and water," Tech. Report, Kampala, 2002.

[7] N. E. Banadda, F. Kansiime, M. Kigobe, M. Kizza and I. Nhapi, Land-use-nonpoint source pollution: a threat to Muchison Bay water quality in Uganda. Proceedings of the International Forum on Water and Food, Vientiane, Lao People's Democratic Republic, pp. 45-52, 2006.

[8] L.M. Campbell, J.S. Balirwa, D.G. Dixon and R.E. Hecky , "Biomagnifications of mercury in fish from ThrustonBay," Napoleon Gulf, Lake Victoria, East Africa, African J. Aquat. Sci., vol. 29(1), pp. 91-96, 2004

[9] R.J. Kimwaga, D.A. Mashauri, F.Bukirwa, N. Banadda, U.G. Wali, I. Nhapi and I. Nansubuga, "Modelling of non-point source pollution around lake victoria using swat model: a case of simiyu catchment tanzania," Open Environ. Eng. J., vol. 4, pp. 112-123, 2011.

[10] R. J.Kimwaga, D. A. Mashauri, F. Bukirwa, N. Banadda, U.G. Wali and I. Nhapi, "Modelling the Impact of Land Use Changes on Sediment Loading into Lake Victoria Using SWAT Model: a case of simiyu catchment," Tanzania, Open Environ. Eng. J., vol. 4, pp. 112-23, 2011.

[11] N. Banadda, F.Ayaa, I. Nhapi, U.G.Wali, R.J. Kimwaga and D.A.Mashauri, "Modeling diffusive flux of non point source pollutants in lake victoria: a comparison study of fick's law and the fokker-planck law," Open Environ. Eng. J., vol. 4, pp. 105-111, 2011

[12] Dubi, A. M., "Overview of hydraulics and simiyu river sediment inputs into Magubay," Lake Victoria, Tanzania, University of Dares-Salaam, J. Eng. Tech., vol.1, pp. 71-83, 2006.

[13] J.F. Rwetabula, Smedt, M. De Rebhun, and F. Mwanuzi, "Transport of micropollutants and phosphates in the Simiyu river (tributary of Lake Victoria)," Tanzania. International Conference on Environmental Science and Technology, January 23-26, New Orleans, Louisiana, USA, 2004.

[14] D.M.M. Mulungu and S.E. Munishi:Simiyu, "River catchment parameterization using SWAT model," J. Sci. Direct. Phys. Chem. Earth, vol. 32, pp. 1032-1039, 2007.

[15] F. Mwanuzi, "Comparison of two different transport models to predict sediment transport: Simiyu River," Tanzania. J. Eng. Technol., Univ Dar-es-salam, vol.1, pp. 60-70, 2006.

[16] S.L.Neitsch, J.G. Arnold Kiniry, J.R. Williams and K.W.,King, "Soil and water assessment tool theoretical documentation version 2000." Texas Water Resources Institute, College Station, Texas, 2002.

[17] P.M. Ndomba, F. Mtalo, and A.Killingtveit, "The suitability of SWAT model in sediment yield modelling for ungauged catchments: acase of Simiyusubcatchment," Tanzania. Proceedings of the $3^{\text {rd }}$ International SWAT Conference, $11^{\text {th }}-15^{\text {th }}$ July, EAWAGZurich, Switzerland, pp. 61-69. 2005.

[18] T.Z. Xu, "Water quality assessment and pesticide fate modelling in the Lake Naivasha area," Kenya. Water Resources Survey, Enschede, ITC, 1999

(C) Kimwaga et al.; Licensee Bentham Open.

This is an open access article licensed under the terms of the Creative Commons Attribution Non-Commercial License (http://creativecommons.org/licenses/by-nc/3.0/g) which permits unrestricted, non-commercial use, distribution and reproduction in any medium, provided the work is properly cited. 